\title{
A Multifaceted Challenge to Enhance Multicriteria Decision Support for Energy Policy
}

\author{
Magdalena Krysiak ${ }^{1}$ and Aldona Kluczek ${ }^{2, *(D)}$ \\ 1 An Independent Researcher (Alumna), Warsaw University of Technology, 02-524 Warsaw, Poland; \\ krysiak.magdalena@o2.pl \\ 2 Faculty of Production Engineering, Warsaw University of Technology, 02-524 Warsaw, Poland \\ * Correspondence: aldona.kluczek@pw.edu.pl; Tel.: +48-22-234-8133
}

check for

updates

Citation: Krysiak, M.; Kluczek, A. A Multifaceted Challenge to Enhance Multicriteria Decision Support for Energy Policy. Energies 2021, 14, 4128. https://doi.org/10.3390/en14144128

Academic Editor: Patrycja Hąbek

Received: 31 May 2021

Accepted: 6 July 2021

Published: 8 July 2021

Publisher's Note: MDPI stays neutral with regard to jurisdictional claims in published maps and institutional affiliations.

Copyright: (C) 2021 by the authors. Licensee MDPI, Basel, Switzerland. This article is an open access article distributed under the terms and conditions of the Creative Commons Attribution (CC BY) license (https:// creativecommons.org/licenses/by/ $4.0 /)$.
Abstract: The necessity to enhance multicriteria decision in the industry is challenging to support the current energy policy. European Union regulations and guidelines provide the guideline for minimalizing environmental harms but are not enough in their actions for providing effective sustainability assessment. None of the available standalone assessment methods do capture the comprehensibility of multicriteria decision-making. The aim of this paper is to demonstrate a challenge to incorporate the multicriteria sustainability decision-making method to mainstream energy policy, which is lacking in European Union policies. The novelty of the research lies in constructing a multicriteria sustainability approach for assessing energy technologies performance for embodying into a mainstream energy policy. In this study, the multicriteria decision-making-an approach combining life cycle-based methods, analytical hierarchy process, as well as macroeconomic analysis, was used to demonstrate the applicability of the method based on three photovoltaic technologies. The results showed that sustainability assessment supported with multicriteria decision allows to better understand analyzed factors influencing the energy technology, contributing to selection of the best sustainability technology according to the realization of an energy policy. It was proved based on a real example of photovoltaics, where string ribbon technology represents the most sustainable along its life cycle, with a 0.503 sustainability score. The study highlighted the challenge to embody the integrated method assessing sustainability-oriented technologies into an energy policy. This challenge regarding example evidence places emphasis on the decision-making process to realize an energy policy and in consequence, to improve enterprise sustainability performance.

Keywords: sustainability assessment; energy technology; multicriteria decision-making; analytical hierarchy process; macroeconomic analysis; energy policy

\section{Introduction}

Rapidly growing demand for natural resources combined with constantly increasing technological progress have resulted in adverse changes in the environment, which in turn influence general human prosperity or wealth generation. International organizations and governments concerned with such situations have been debating the environment, sustainability, and promotion of an energy policy in many documents for many years [1-4].

Since national authorities aim to respect these documents, an energy policy gains importance in connection to its assessment methods, becoming a catalyst in economic growth and social development in all countries. The significant role of modeling tools for sustainability assessments influencing sustainability and policy-relevant issues was discussed in [5]. The existing energy policies which draw attention to the energy use from renewable sources providing $\mathrm{CO} 2$ emission limit targets [4] came under criticism by [6] but neither consider the sustainability of energy systems nor any assessment methods. This fact opens room for potential initiatives for drawing decision-making approaches meeting the sustainability concept. Integration of assessment methods contributed to support the 
selection of decision-making processes for sustainability as stated in similar papers [7]. Hence, a need for enabling potential action to adopt an integrated sustainability assessment method within the energy policy at the regional and national levels is still missing.

Many MCDA methods based on life cycle analyses are very popular and mostly used for assessing technology [8-10], energy systems [11-13], or to support decisionmaking processes for energy technology selection [14,15] or energy projects [16]. Other methods based on fuzzy logic used more sophisticated calculations for sustainability evaluation [17-19].

Having the above-mentioned background, an increase in awareness of the implementation of the sustainability initiatives related to renewable energy is required to be undertaken with respect to economic, social, and environmental dimensions. In this context, ensuring those dimensional criteria impose to develop methodological assessment approaches to support multicriteria decision processes for energy sustainability. Some studies assessed technology performance from the environmental point of view only [20], others dealt with the economic assessment [21], social impact assessment [22], or integrated insight [23]. Some papers examined the regular assessment methods (Energy Management Evaluation or tax policies) broadly from the environmental management perspective [24,25], but those assessment models are too complex to assess energy technology accurately in addressing the targeted industry. This paper provides a review of various MCDM methods examined in Section 2. A development in this field has been done by allowing to consider the application of renewables in a specific macroeconomic decision situation over MCDM techniques.

Although many sustainability assessment frameworks and tools have been examined [8,26-29], none of them do integrate macroeconomic analysis, sustainability issues, and life cycle assessment within the renewable energy multicriteria approach simultaneously, especially in the context of energy policy. No comparable methods were examined in the relative literature. That is why this paper presents a sustainability assessment that focuses not only on trade-offs between environmental, economic, and social aspects while producing the energy by renewables, but on their whole life cycle-from raw material extraction to the final disposal. The assessment may be performed by selecting measurement indicators proclaimed by the EU energy policy or developed by scientists and applying them to the mainstream energy policy [30].

Therefore, this study fulfills an existing research gap concerning the lack of renewable sustainability assessment considering macroeconomic analysis in the current MCDM frameworks. The presented assessment approach is based on a combination of life cycle sustainability analysis (LCSA), AHP, PESTLE within the MCDM framework. In this paper, the PESTEL was used to reach a trade-off prior to the start of the ranking of technologies through the AHP to be assessed within LCSA. A way of sustainability assessment is LCSA used to evaluate impacts caused during the product life cycle. Because the LCSA deals with numerous criteria, measures, and indicators, they are grouped and contained within the three dimensions of sustainability (environmental, economic, social). Then, the sustainability criteria are directly connected to decision-making processes that find the trade-offs between them and support the selection of the most sustainable technologies [8]. The AHP was used to provide the interdependence of criteria and finding a solution to complex multicriteria problems [16].

Even though there are numerous examples of multicriteria-based decision processes, multifaceted challenges still exist in order to support energy policy in its feasibility (Table 1). Considering challenges, the authors' intention is to develop a multicriterial, integrative approach in order to effectively assess and choose the most appropriate energy technology alternative embraced within MCDA to incorporate into the mainstream energy policy. This method, which has not been treated yet, also addresses features considering a relationship between economic, environmental, and social issues within one unified methodological sustainability approach. 
Table 1. Multifaceted issues: drivers, challenges, and opportunities for supporting energy policy.

\begin{tabular}{|c|c|c|}
\hline Drivers & Challenge & Opportunities \\
\hline \multirow{3}{*}{ Scientific soundness } & $\begin{array}{l}\text { Lack of analytical methods in the EU } \\
\text { current energy policy }\end{array}$ & $\begin{array}{l}\text { Develop a sustainability method for assessing energy } \\
\text { technology which helps find interaction between } \\
\text { technology through influencing factors and the divers of } \\
\text { energy policy. }\end{array}$ \\
\hline & $\begin{array}{l}\text { Use of weights in assessment methods } \\
\text { based on scientific community }\end{array}$ & $\begin{array}{c}\text { Capability of handling the weights using criteria values } \\
\text { assigned by scientific individuals based on imprecise } \\
\text { qualitative and quantitative data based on [27]. }\end{array}$ \\
\hline & $\begin{array}{l}\text { Support decision making by integration } \\
\text { other methodologies }\end{array}$ & $\begin{array}{l}\text { Integrate assessment methods to achieve better } \\
\text { interpretation thanks to the unified sustainability } \\
\text { framework and find out further methodological } \\
\text { development [8]. }\end{array}$ \\
\hline Availability and utility & $\begin{array}{l}\text { Use of simplicity in a structure of } \\
\text { assessment methods }\end{array}$ & $\begin{array}{l}\text { Possibilities to present and interpret the results of } \\
\text { assessment in multifaceted context depending on } \\
\text { selection of alternative and manage them [31]. }\end{array}$ \\
\hline Regulation issues & $\begin{array}{l}\text { Provide harmonics in terms of energy } \\
\text { technology assessment }\end{array}$ & $\begin{array}{c}\text { Provide a procedure for embodying the energy } \\
\text { sustainability assessment method into mainstream of } \\
\text { energy policy. }\end{array}$ \\
\hline
\end{tabular}

Source: own elaboration.

The novelty of the study relies on an attempt to construct a multicriteria sustainability approach for assessing the three photovoltaic technologies' performance for embodying the mainstream energy policy, which lacks in the EU current policy. This approach combines several methods based on macroeconomic analysis (PESTEL), weighting for finding dependencies between criteria and their indicators, and LCSA, which are framed into the energy decision-making cycle, will facilitate the assessment and selection of appropriate energy technology. The presented model outlines the novelty through:

- the inclusion of the sustainability assessment approach in mainstream policies,

- the incorporation of several methods that have not been considered before as a whole to build a structured, standardized, and systematic sustainability assessment (4STech) for energy technology selection,

- taking into account a macroeconomic perspective,

- showing the sequence of making the sustainability assessment for technology.

In addition to the novelty, the necessity of doing research on the integrative approaches combining sustainability and supportive multicriteria decision-making methods was stressed by researchers [19]. The motivation of the study is to: (1) design a formal method for technology selection that can help to develop and implement energy policy complying with European Union and United Nations standards; (2) address the lack of a standardized method for assessing the sustainability of technology; (3) define the effect of sustainability assessment on the local economy and companies; (4) intend a proposal method to be incorporated into national energy policies to encourage the industrial plant to act actively; (5) enumerate limitations to the integrated framework.

\section{Literature Review on Sustainability-Oriented Energy Technology for Supporting Energy Policy}

\subsection{Revealing Sustainability-Oriented Energy Technology Assessment}

Sustainability is the leading development concept providing to meet "the needs of the present without compromising the ability of future generations to meet their own needs" coming from the 'Our Common Future' report, and balancing economic growth, environmental protection, and social equality dimensions within Elkington's triple bottom line [32]. 
A huge discussion in extant literature on the area of the sustainable assessment methods to support decision-making was performed [33,34] starting its own "adventure" with the life cycle assessment (LCA), life cycle sustainability assessment (LCSA) through integrated methods. However, the limitations of LCA provide difficulties in the identification of the most relevant impact factors [35]. Hence, a combination with others methods, involving weighting of criteria, like multicriteria decision making (MCDM), overcomes complicated problems with various influential factors [36] and uncertainty in estimating criteria weights [37]. LCSA as a joint-venture of LCA-based methods was designed to evaluate a scale of environmental, economic, and social changes, taking into account product systems' life cycle $[17,28]$. Life cycle analysis (LCA) and life cycle costing (LCC) give the quantitative measures for economic and environmental issues respectively, while social life cycle analysis (SLCA) presents social concerns representing qualitative and semi-quantitative measures. Thanks to LCSA, separate LCA, LCC, S-LCA can be applied independently but if coupled with other methods under specific feasibility (consistency) conditions like data envelopment analysis (DEA), PESTLE, analytical hierarchy process (AHP) create LCA-based benchmark for sustainability verification. This combination of the recently very promising LCA with a non-parametric linear programming tool like DEA found applications in various sectors in the last years [28-32], giving a solid framework for starting an energy sustainability assessment.

The robustness of the LCA (methodical features) provides for a modeling approach and possibilities to choose LCSA methods under a certain condition (e.g., justification of choice made). The advantage of the robust LCA over other ones is its data-driven methodology and if combined with the relevant methods, it might provide a holistic view for sustainability policy. Features like functional unit, system boundary, quality data arguably strongly affect the results of considered studies (Sala et al., 2016). Moreover, LCSA measures require consideration of numerous indicators that might have different levels of significance. Because of that, to make an authoritative assessment, it is advised to incorporate multicriteria decision-making (MCDM) tools. A classification of MCDM models used in energy planning together with their extensive review was carried out in [36]. Dong et al. (2019) proposed an extended MCDM model to rank the energy systems [11]. Different combinations of MCDA are based on integration of the existing methods with expert opinions like AHP. The use of the AHP showed a challenge in the evaluation of the efficiency of energy policy and even with the combination of MCDM methods [38].

A more sophisticated method, which is the neutrosophic multi-objective optimization on the basis of ratio analysis technique framed in MCDA for comparing achievements in development of sustainable energy, was used. Amongst multicriteria approaches, the VIKOR (Vlse Kriterijumska Optimizacija Kompromisno Resenje) method is widely used in the energy-related decision-making process, e.g., for evaluating applicability of a sustainable plant [39], energy system [10]. Together with other ranked methods like TOPSIS, AHP, ANP (e.g., TOPSIS-AHP [40], ANP and VIKOR [41]; fuzzy VIKOR and AHP [42] were employed for impact analysis or to assess the alternative energy-related problem (e.g., energy technology, renewable sources, energy policy, production plant, etc.). A number of reviews have prompted the design of fuzzy-based approaches such as fuzzy AHP, TOPSIS, VIKOR which can be used for determining weights for sustainability criteria in selection energy resources [10].

Apart from the above-mentioned hybrid methods, Cinelli et al. (2014) depicted the possibility of the application of PROMETHEE, AHP, MAUT [27], and ELECTRE or integrated (e.g., AHP and PROMETHEE) for assessing sustainability performance against sustainability criteria [43]. Table 2 summarizes some of these studies on decision-making methods used in the related research areas. 
Table 2. Survey of selected scientific papers using decision-making methods for a sustainability assessment of energy technologies.

\begin{tabular}{|c|c|c|}
\hline Methods Used & Area of Research & References \\
\hline ANP & Ranking of renewable energy resources using 5 indicators & {$[39,44]$} \\
\hline ANP and VIKOR & MCDM-based evaluation of renewable energy sources & [41] \\
\hline VIKOR and AHP & Assessment of energy production technologies & [42] \\
\hline TOPSIS and AHP & $\begin{array}{l}\text { Selection of sustainability-oriented technology; maintenance } \\
\text { strategy selection in hydroelectric power plants }\end{array}$ & [40] \\
\hline Fuzzy TOPSIS & Assessment of hybrid energy systems & [45] \\
\hline LCA and AHP & Sustainability assessment of power plants & [46] \\
\hline LCA and MCDM & Sustainability assessment for (renewable) energy technologies & {$[8,27,47]$} \\
\hline LCSA (LCA + LCC + SLCA) & $\begin{array}{l}\text { Sustainability impact assessment of the biofuel and biomass } \\
\text { using quantitative indicators related to environmental, } \\
\text { economic, and social issues }\end{array}$ & {$[28,48]$} \\
\hline $\begin{array}{l}\text { DEA and LCA/DEA and energy } \\
\text { LCA-based approach }\end{array}$ & Sustainability assessment of energy systems & {$[49,50]$} \\
\hline $\begin{array}{l}\text { Hybrid multicriteria decision-making } \\
\text { approach-PESTEL and AHP and SLCA }\end{array}$ & $\begin{array}{l}\text { Sustainability assessment of energy technology for enhancing } \\
\text { decision using classical criteria and } 10 \text { indicators based on }\end{array}$ & the authors \\
\hline
\end{tabular}

For the purpose of this paper, the analytical hierarchy process (AHP) was chosen for weighting criteria. This decision was backed by the scientific comparison of various MCDM methods. The study conducted on 4712 publications determined that AHP was the most commonly used tool in the context of the energy sector [51]. This approach seems particularly useful when comparing and selecting different technologies. Although MCDM suffers from uncertainties in assessment [47], different criteria levelling (weight deviation) and evaluation accuracy [52], but if combined with other methods, e.g., LCA, TOPSIS, fuzzy sets overtake disadvantages over the standalone ones in MCDM problems.

Additionally, no research was carried out to show an integrated method consisting of PESTEL, LCA-based approaches, and AHP to assess and rank energy technology, especially photovoltaic panels. Although many studies treat LCA and AHP as energy systems, PESTEL was not found as compatible for integration with another MCDM approaches. PESTEL is designed to primarily analyze possible energy technologies to select these renewable energy technologies that should be treated in further steps. PESTEL as a macroeconomic tool is used to analyze the political, economic, social, technological, legal, and environmental company's situation. In this context, PESTEL is used in the model as a supportive decision in selection of the energy technology, revealing multiple impacts from a separate category in the external environment.

Because renewable energy technologies are sustainability-oriented, it is not known which type of technology is the most appropriate of the options. Therefore, an integrated assessment method should be an appropriate methodology to handle this selection problem. On the other hand, the MCDM methods can help avoid vagueness/imprecise of quantitative indicators and uncertainty in their calculation by involving the domain expert's judgements in the decision-making process $[53,54]$. Hence, it was reasonable to apply values for sustainability criteria and their sub-criteria (indicators) [55] based on preferences of different individuals, researchers, plants' decision makers, stakeholders, from the relevant scientific articles. Having the above-mentioned concerns, a challenge is to support a decision-making process for enhancing energy policy. This in turn could solve a few conflicting sustainability factors. The assessment method integrates PESTEL to prioritize technologies among energy renewables and the AHP for ranking I level-criteria and II level criteria by examining sustainability indicators (environmental, economic, and social) to be used in life cycle sustainability assessment to select the best energy solution. Within this 
method, the AHP allows the use of criteria values assigned by scientific individuals based on their preferences developed after reviewing literature and the plant's judgements.

Based on the comparison of the corresponding multicriteria decision-making methods for supporting sustainable energy policy, this paper highlights distinctly a research gap of the lack of a structured, standardized, and systematic sustainability assessment method which is helpful to provide a rational technology selection in the sustainable energy decision-making cycle.

\subsection{Problem Statement}

In the light of the reviewed literature, the authors define multifaceted problems in the technology assessment in terms of sustainability for the photovoltaics field, the fulfillment of which determines the possibility of the development of the energy policy and strengthen renewables sector through the implementation of the integration method. The following problems are:

1. The lack of integrated methods considering macroeconomic insight/views on renewable technologies. Additionally, multicriteria methods do not consider/treat macroeconomic perspective in themselves;

2. Decisions makers like governments do not take into consideration the potential for applying assessment methods into mainstream energy policy, not only at the national level but also in local industrial communities,

3. Governments do not offer supportive model/procedure for assessing the sustainability of technologies, especially renewables;

4. The lack of incorporation of a structured, standardized, and systematic sustainability assessment (4STech) for energy technology selection, especially in the target sector.

Facing the current problem and future EU initiatives related to renewable technologies, this research justifies the necessity of embodying this integrated model in the future energy policy of various countries.

\section{Materials and Methods}

This section describes a conceptual and methodological energy-anchored sustainability assessment framework for enhancing energy policy. A procedure depicts an iterative, structured sequence of activities, being a combination of LCSA, AHP, and PESTEL for assessing technology sustainability in terms of energy (see Figure 1). In this case, the authors, taking the advantages of these methods into account, demonstrate a multicriteria decision-making procedure for the sustainability assessment of renewable technologies. The applicability of the method is verified based on selected photovoltaic technologies. The methodological framework is seen as a comprehensive chain of tools and actions. This framework consists of four main steps, all of them are based on the original ISO 14040 standard [56,57] and integrates the following methods: (1) LCSA, which is concerned with products and systems assessment during their life cycle; (2) AHP, which aims to support the decision-making process by taking various criteria into consideration.

\section{Methodology for Energy Technology Assessment}

A suggested energy-anchored sustainability assessment framework, as seen in Figure 1, is described as follows:

1. Develop a context of technology assessment for enhancing energy policy. At the initial stage, the context of the study is identified, providing information about a specific goal and scope. In addition, system boundaries, assumptions, and limitations are sketched. In this part, sustainability aspects that are affected by the energy sector are allocated to a macroeconomic analysis using PESTEL. Incorporating this analytical tool, PESTEL, into the "partial" stage methodology allows for understanding a landscape environment for the energy industry, influencing sustainability through the deployment of the political, economic, social, technological, legal, and environmental factors. These factors correlate with technologies that influence industrial sustainabil- 
ity, leading to determine "the strength and weaknesses of the different production pathways" [35]. For clarification, this step provides information with which energy technology should be analyzed and ranked in the next stages;

2. Define energy technology alternatives. This stage of the study suggests energy technology alternatives as a result of PESTEL analysis (see Table 3), so that it is comparable in three scenarios. Further, these alternatives are assessed in terms of sustainability to select the best type of energy solution (here photovoltaic module). Within this stage, an overview of technical information is also provided, consisting of (1) a product/system description with a list of its alternatives with their characteristics;

(2) functional units that will represent the performance of the system under analysis; as well as (3) system boundaries, limitations (e.g., data availability), and assumptions (e.g., region to be considered), for the LCSA;

3. Analyze data collection using life cycle inventory (LCI). It collects the energy-related data from primary and secondary sources. Primary data are measured directly by the organization. Two experts were assigned (one operational manager and one employee and a scientist) for conducting the study. It usually comes from the companies' databases regarding its production performance in environmental, societal, and economic context. Meanwhile, the secondary data can be gathered from companies' stakeholders, e.g., suppliers. Additional sources of information can be derived by the organization from industry interviews, scientific literature, specific databases, or using statistics;

4. Rank technologies. Prioritization is conducted for the alternatives of photovoltaic modules. This phase encompasses two steps:

i. Identify criteria impact assessment. The identification of categories is based on the sustainability dimensions. Each sustainability dimension is being analyzed in the context of standalone methods-life cycle assessment (LCA), social life cycle assessment (SLCA), and life cycle costing (LCC) respectively. For LCA, a vast variety of environmental (sub-)criteria can be obtained by the application of the well-developed methods for life cycle impact assessment on sustainability, such as Impact 2002+, ReCiPe, TRACI2.0 (Tool for the Reduction and Assessment of Chemical and Other Environmental Impacts) $[8,58,59]$. These methods enable the transformation of life cycle collection data into a set of environmental indicator values. LCC costs might entail pre-production, production, and post-production costs. In the LCC, criteria that describe the added value should also be included. These are net present value or return on investment. For the social dimension, some possible indicators should be used. Literature contains a wide variety of indicators that can be applied in social LCA. In this context, decision-makers assigned to the study can select criteria on the basis of organization's circumstances and their preferences. In this case, aspects to be measured are characterized by a very wide scope. They can be addressed to single workers as well as to society as a whole, on which organization can exert impact. There is just a few guidelines with examples of social indicators, all of them are gathered and presented in article [22]. These criteria differentiate various stakeholders and assign different criteria to them. Since impact categories were defined, associated criteria staying in line with predefined sustainability dimensions are identified. The determination of sustainability criteria was carried out based on Tables 4 and 5 .

ii. Define criteria's weights using the AHP. The data concerning different criteria are described by various units and scales. Therefore, all the present values must be converted into a dimensionless and unitary equivalent, using "benefit function" or "cost function" [60]. At this point, weights of the criteria and normalized data are provided. Then, the normalized values of each criterion must be multiplied by the corresponding weight value (level II weights), achieving the criterion score. The final result for each of the selected alternatives consists 
of the sum of partial results for every sustainability dimension multiplied by its relative weights (level I weights).

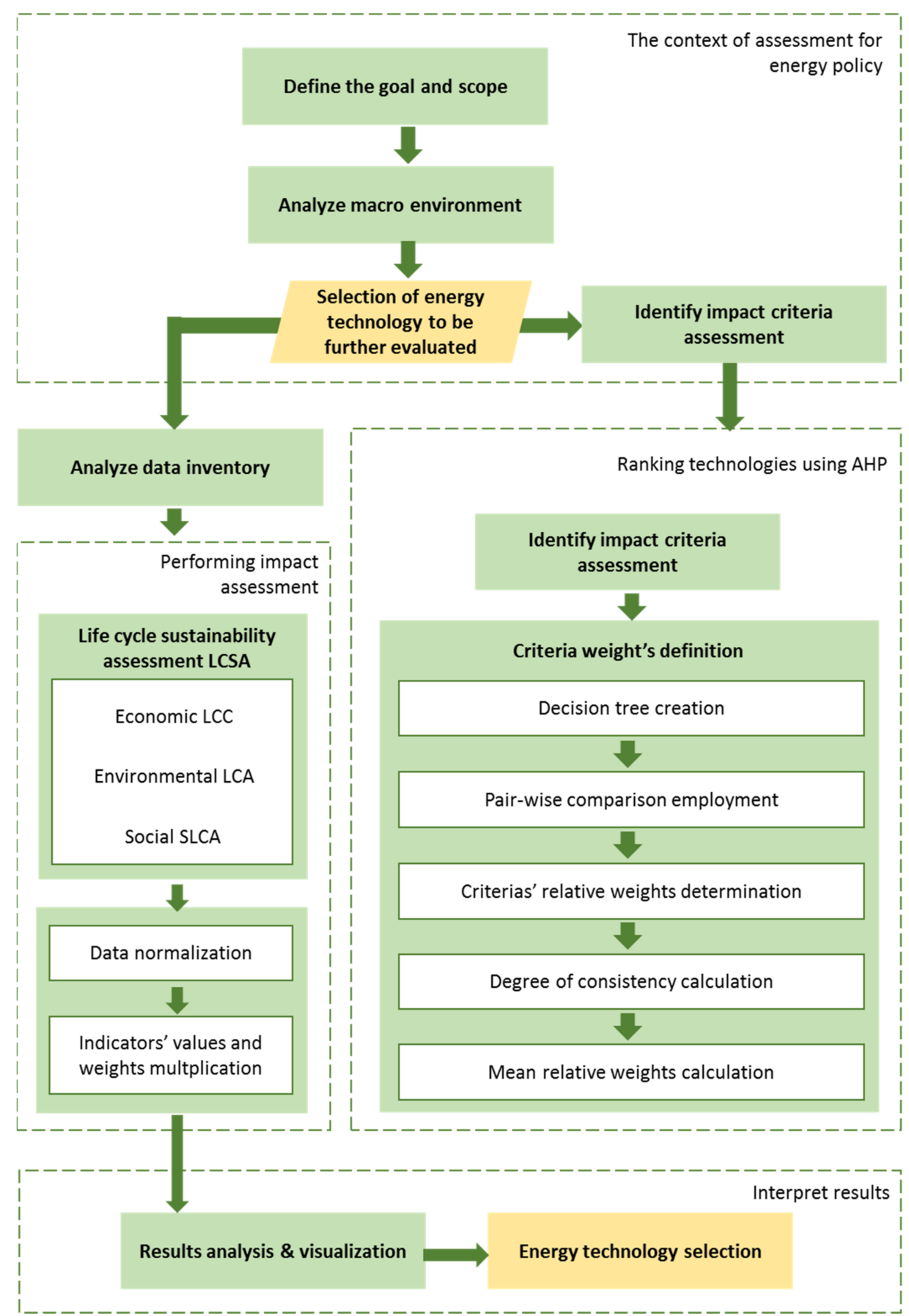

Figure 1. Schematic diagram of multicriteria decision-making approach for life cycle sustainability assessment. Source: own elaboration.

Once the appropriate data concerning the impact of selected criteria is collected, the importance of each of the criterion must be determined, by assigning corresponding weights which are determined by AHP. This process consists of a few steps presented in [61]. The prioritization is defined using Saaty's scale [61]. In order to verify a consistency of decision-makers' evaluations, the consistency index (CI) is calculated. When relative weights of criteria are determined, and consistency of the evaluations are provided, the mean relative weights should be calculated. It can be performed 
by averaging the relative weights, calculated by each of the decision-makers and for every criterion;

5. Perform impact assessment. This step of the methodology accounts for the LCSA evaluation for impact assessment, integrating LCA, LCC, SLCA. A calculation procedure is based on criteria selected in the previous step (3.2). At this level, all the data required to the evaluation needs to be normalized and analyzed with regards to the weights developed in the previous step;

6. Interpret results and analysis. Results of the assessment will be investigated in accordance to the stated goal of the study. Moreover, the discussion on the assessment and its 'outcomes are provided.

\section{Results from the Study}

The following section provides results from the application of a sustainability assessment methodology for different photovoltaic module technologies. These types of renewable energy sources were selected on a basis of conducted PESTLE analysis.

\subsection{Defining the Goal and Scope}

The proposed assessment is based on the real case from the industrial plant obtaining subsidies from Polish public institutions. In order to fulfill the requirements for governmental support, it needs to incorporate a goal of becoming an industrial plant shifted towards sustainability. To meet this objective, the company decided to implement an assessment method for choosing the most appropriate renewable technology for their facility. The initiative of the company was to check which type of selected renewable technologies is characterized by the highest level of compliance to the environmental, social, and economic issues. Due to the attempt of starting with the sustainability assessment, the company decided to use the data from the available scientific literature. This study was not based on individual data from specific manufacturers. The reason behind it is the fact that the performance of selected technologies produced by different organizations may vary and that would make the assessment not represented within the context of general technology evaluation. Therefore, the assessment was conducted upon relevant aggregated data (criteria weights and scores) that were available in various reports, research papers, and publicly accessible academic datasets $[62,63]$. Boundaries for the life cycle sustainability assessment concentrate on the crystalline silicon solar cells including crystalline polycrystalline (multi-Si), monocrystalline (mono-Si), and string ribbon (ribbon-Si) solar panels (see Figure 2).

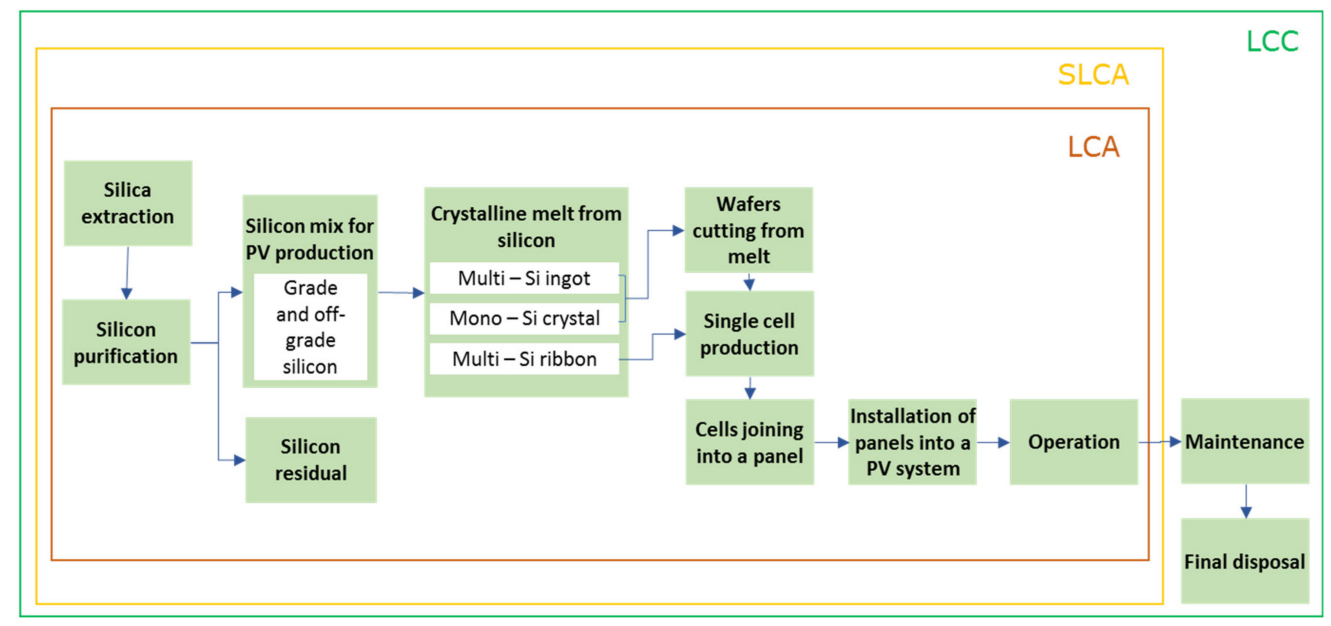

Figure 2. Boundaries for the life cycle sustainability assessment (redrawn with significant changes based on [64]). 
The analysis was conducted with respect to Poland and European conditions. In comparison to two other alternatives, the solar energy was selected as the alternative with the highest potential and a subject of the further analysis. This statement that solar energy is the optimal source of renewable energy was highlighted in the following research [65].

\subsection{Define Energy Technology Alternatives}

In the PESTLE analysis, the following renewable energy resources were selected: solar power (S), bioenergy (B), and wind energy $(\mathrm{W})$ as they are the most intensely growing renewable resources industries globally in terms of generated electricity. The conducted PESTLE analysis is presented in Table 3.

Table 3. PESTLE analysis for selected renewable energy sources.

\begin{tabular}{|c|c|c|}
\hline \multirow{3}{*}{ Political } & $S$ & $\begin{array}{l}\text { The Polish PV industry is actively supported by the government, for instance, } \\
\text { governmental activities are aimed at strengthening national energy security by focusing on } \\
\text { foreign dumping prevention in the domain of solar energy. There are also numerous public } \\
\text { programs focusing on solar energy development that target domestic businesses-such as } \\
\text { Energia Plus or PolSEFF2. }\end{array}$ \\
\hline & W & $\begin{array}{l}\text { Even though Poland has one of the biggest wind farms capacity in EU, the situation of the } \\
\text { domestic wind power market is difficult [66]. Current regulations have effectively stopped } \\
\text { growth in the industry that is stale since } 2016 .\end{array}$ \\
\hline & B & $\begin{array}{l}\text { Bioenergy related regulations are influenced by European Union directives (such as RED } \\
\text { developed by European Commission) that aim at the development of biogas and biofuels as } \\
\text { it may diversify energy sources and increase national energy security [67]. }\end{array}$ \\
\hline \multirow{3}{*}{ Economic } & $S$ & $\begin{array}{l}\text { Photovoltaics are characterized by the highest rate of weighted-average levelized cost of } \\
\text { electricity (LCOE) of utility scale-82\% over 2010-2019 in comparison to two other } \\
\text { alternatives [68]. In 2020, the year to year Polish market turnover growth reached } 25 \% \text { [69]. }\end{array}$ \\
\hline & W & $\begin{array}{c}\text { As of 2016, installed capacity in the wind energy industry was about } 5.8 \mathrm{GW} \text {, in } 2020 \\
6.3 \mathrm{GW} \text {. The industry growth in recent } 4 \text { years is negligible compared to the previous period. } \\
\text { Due to strict regulations, investors are not eager to enter the industry and prefer to locate } \\
\text { the investment elsewhere [70]. Very high investment costs per one turbine-from } 268,817 \text { to } \\
806,450 \text { USD [71]. }\end{array}$ \\
\hline & B & $\begin{array}{l}\text { Biomass industry had the highest real economic and market potential [72]. Poland consists } \\
\text { in } 60 \% \text { of agricultural land that makes biomass easily available [66]. The investment costs } \\
\text { amount to a minimum of } 13,440 \text { USD up to up to few hundred thousand USD [71]. }\end{array}$ \\
\hline \multirow{3}{*}{ Social } & $S$ & $\begin{array}{c}\text { In the photovoltaic sector, there were } 3100 \text { people employed in } 2020 \text { in Poland [73]. } \\
\text { According to the European Social Survey from 2016, 87\% of Polish citizens would like a } \\
\text { large amount of electricity to come from solar energy, making it the most popular option of } \\
\text { renewable energy sources in Poland [74]. }\end{array}$ \\
\hline & W & $\begin{array}{c}\text { In the Polish wind energy sector, there were } 3000 \text { people employed in } 2020 \text { [73]. According } \\
\text { to the European Social Survey from 2016, } 82 \% \text { of Polish citizens would like a large amount } \\
\text { of electricity to come from wind energy, making it the second most popular option of } \\
\text { renewable energy sources in Poland [74]. }\end{array}$ \\
\hline & B & $\begin{array}{l}\text { In the Polish bioenergy sector, } 29,600 \text { people were employed in 2020, which ranks this } \\
\text { industry the highest in comparison to alternatives in terms of employment [73]. According } \\
\text { to the European Social Survey from } 2016,53 \% \text { of Polish citizens would like a large amount } \\
\text { of electricity to come from biomass, making it the fourth most popular option of renewable } \\
\text { energy sources in Poland [74]. Potential biomass land use might compete with food } \\
\text { generating agriculture areas, impacting social stability [35]. }\end{array}$ \\
\hline Technological & $\mathrm{S}$ & $\begin{array}{l}\text { Average panel lifetime is } 30 \text { years [75]. Requires little maintenance during its lifetime [76]. } \\
\text { In recent years, number of patents within the domain of solar energy has been constantly } \\
\text { growing. In year 2016, the amount of submitted patents related to solar energy reached } \\
200,000 \text {, making it the most innovative renewable energy source in that matter [77]. }\end{array}$ \\
\hline
\end{tabular}


Table 3. Cont.

\begin{tabular}{|c|c|c|}
\hline \multirow[b]{2}{*}{ Technological } & W & $\begin{array}{l}\text { Expected wind turbine lifetime is } 20-25 \text { years [76]. In recent years, a number of patents } \\
\text { within the domain of wind energy has been constantly growing. In the year 2016, the } \\
\text { amount of submitted patents related to wind energy reached 100,000, making it the second } \\
\text { most innovative renewable energy source in that matter [77]. }\end{array}$ \\
\hline & B & $\begin{array}{l}\text { Biomass generator expected lifetime is } 20,000 \mathrm{~h} \text { (approx. } 2 \text { years) [78].In recent years, a } \\
\text { number of patents within the domain of energy gained from biomass has been constantly } \\
\text { growing, but not as rapidly as two other analyzed sectors. In total, the number of patents } \\
\text { related to gaining energy from biomass is considerably lower than the number of patents in } \\
\text { alternative sectors analyzed in this paper [77]. }\end{array}$ \\
\hline \multirow{3}{*}{ Legal } & S & $\begin{array}{c}\text { Photovoltaic investments are being supported by public funds via dedicated programs that } \\
\text { target domestic enterprises, i.e., "Energia Plus” loan program for small and } \\
\text { medium enterprises. }\end{array}$ \\
\hline & W & $\begin{array}{l}\text { Building a wind power generator requires long waiting time for authorizations and } \\
\text { construction permits [71]. Permits also depend on topographic geology [79]. Investments in } \\
\text { clean energy, including wind energy, are co-financed by the National Fund for } \\
\text { Environmental Protection and Water Management. }\end{array}$ \\
\hline & B & Legal regulations in the domain of generating energy from biomass is unclear [71]. \\
\hline \multirow{3}{*}{ Environmental } & S & $\begin{array}{l}\text { Most PV modules types do not emit any pollutants that might be harmful towards the } \\
\text { environment (with minor exceptions of CIS and CdTe modules that might carry slight } \\
\text { risk) [80]. Production of the latest generation of PV modules requires a considerable } \\
\text { amount of bulk materials which makes the process energy consuming. The upside is the } \\
\text { possibility of even distribution across the country as Poland has a quite uniform sun } \\
\text { irradiance [66]. During PV's operation, there is no noise [81]. }\end{array}$ \\
\hline & W & $\begin{array}{l}\text { Wind turbines may impact wildlife safety, especially birds. Because wind generators } \\
\text { produce electric and magnetic fields, radar or television reception can be destructed. The } \\
\text { presence of wind turbines also increases the possibility of being struck by lightning. } \\
\text { Additionally, wind turbines generate noise during their operation. }\end{array}$ \\
\hline & B & $\begin{array}{c}\text { In contrast to other renewable energy resources, biomass emits greenhouse gases and } \\
\text { pollutants. If biomass is obtained from no waste resources, it requires water and land use } \\
\text { for its growing [82]. }\end{array}$ \\
\hline
\end{tabular}

There are two main types of cell technology-crystalline silicon and thin film. In this paper, the crystalline silicon-based solutions are being examined as they are the most commonly used [83]. There are three main categories of crystalline silicon used in PV modules production: monocrystalline silicon (mono-Si), polycrystalline silicon (multi-Si), and string ribbon (Ribbon-Si), which is part of the polycrystalline silicon family [84]. These three types of technology are compared and assessed in terms of proposed framework.

\subsection{Analyze Data Collection}

In life cycle assessment, primary data that come from the online available EcoInvent database are used. These data are used as an input for impact calculations conducted by the WebService-Energy tool, measuring environmental performance of PV systems. It provides the impact assessment for photovoltaic systems which are small-scale plants of $3 \mathrm{kWp}$ capacity. These concern PV modules which are laminated, integrated, and installed on a roof with 30 years of operation system lifetime. For the sake of the assessment, it was assumed that the analyzed modules are located in Poland.

\subsection{Identify Criteria Impact Assessment}

The first level criteria are sustainability dimensions, while the second level criteria were selected with use of the guidelines provided by the European Technology and Innovation Platform for Photovoltaics. The weights of criteria are secondary data that have been determined on the basis of scientific research. The detailed justification and explanation of 
how the weights were derived for each of the criteria level are presented in Tables 4 and 5 showing the criteria hierarchy as a part of the AHP.

Table 4. Weights of I level criteria.

\begin{tabular}{|c|c|c|c|}
\hline I Level Criteria & Weight & Source & Justification \\
\hline Environmental & 0.333 & \multirow{3}{*}{ [85] } & \multirow{3}{*}{$\begin{array}{l}\text { In the analysis, two other dimensions were also taken under } \\
\text { consideration. They were excluded as not relevant. By using } \\
\text { proportional calculations, the new weights were obtained. }\end{array}$} \\
\hline Economic & 0.350 & & \\
\hline Social & 0.317 & & \\
\hline
\end{tabular}

Source: Own elaboration.

Table 5. Weights of II level criteria.

\begin{tabular}{|c|c|c|c|c|}
\hline Dimension & II Level Criteria & Weight & Source & Justification \\
\hline \multirow{4}{*}{ Environmental } & Acidification & 0.061 & \multirow{4}{*}[85,86]{} & \multirow{4}{*}{$\begin{array}{l}\text { By exclusion of inapplicable criteria and calculating relative } \\
\text { importance based on original percentages, new weights have } \\
\text { been established. }\end{array}$} \\
\hline & Climate change & 0.592 & & \\
\hline & Ecotoxicity & 0.143 & & \\
\hline & $\begin{array}{c}\text { Mineral, fossil \& ren } \\
\text { depletion }\end{array}$ & 0.204 & & \\
\hline
\end{tabular}

Energy payback time and life cycle energy cost take the whole life cycle under consideration, whereas capital costs represent singular costs though, even though high, are rather short-term concern. Even though capital costs are considered as individual expenditures linked to assets that guarantee operational status of the system, in a long term, in which solar systems are considered, they are of lesser importance than a continuous long-term stream that is Energy payback time $\quad 0.444$

Economic represented by energy payback time and life cycle energy cost. Additionally, the importance of energy payback time and life cycle energy cost are assumed to be equal since they are both based on the same ratio between energy that was consumed during the life cycle and the energy that was produced by the system. The difference between them is due to the various points of views and corresponding contexts. Hence, they present equal importance (which equals 1 on the Saaty's scale). Therefore, capital cost is moderately to strongly less important than energy payback time and life cycle energy cost (which equals $1 / 4$ on the Saaty's scale).

\begin{tabular}{ccc}
\hline Life cycle energy cost & 0.444 \\
\hline Capital cost & 0.112 & \\
$\begin{array}{c}\text { Human toxicity } \\
\text { (cancer) }\end{array}$ & 0.421 & [86] \\
\hline $\begin{array}{c}\text { Land use } \\
\text { Human toxicity } \\
\text { (non-cancer) }\end{array}$ & 0.316 \\
\end{tabular}

By exclusion of inapplicable criteria and calculating relative importance based on original percentages, new weights have been established.

Source: own elaboration.

Priorities of indicators are very often a crucial strategic data that a given company wants to protect by all means. Because the gathering of such data is a rather difficult taskvarious institutions do not want to share their decisions, regulations and the knowledge that gives them a competitive advantage. To keep the current study valid, the weights of criteria have been determined on the basis of scientific research. In the case of determining weights of sustainability dimensions, research was used that aimed to assess solar photovoltaic technologies using hierarchical decision modeling [85]. The opinion regarding the criteria priority was determined through organizing an expert panel with nine people experienced in the photovoltaic industry. For criteria included in the environmental and social dimension, another study was used. In this case, the paper has presented sets of weights that could have been applied in the midpoint impact categories-which are exactly 
the weights that were selected in this study [86]. The weight was determined on the basis of judgments gathered within a stakeholder panel, including producers, users, and LCA experts, then calculated using the AHP. In the case of economic criteria, the subjective priorities were made based on desk research [87].

\subsection{Perform Impact Assessment and Interpretation}

Figure 3a and Table 6 shows the performance measurement of selected PV modules concerning each sustainability dimension. The results depict that each of the assessed PVs hold the same position for each of the dimensions. The general measurement outcome (0.503) suggests that the best technology—string ribbon-exceeds other ones in every of the analyzed sustainability dimension. The analogical relation applies for the worst of the analyzed alternatives.

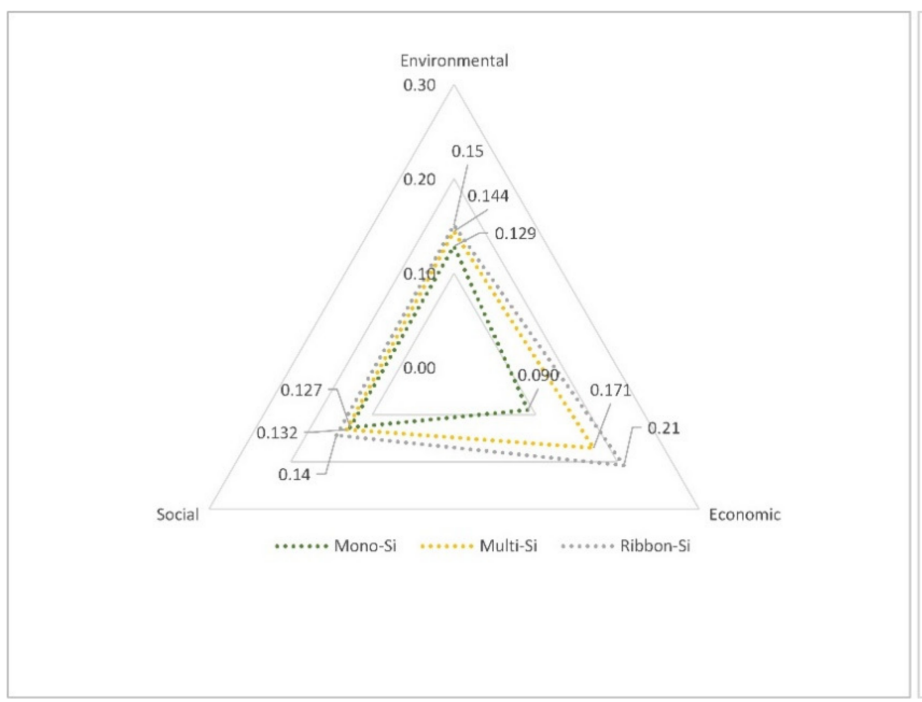

(a)

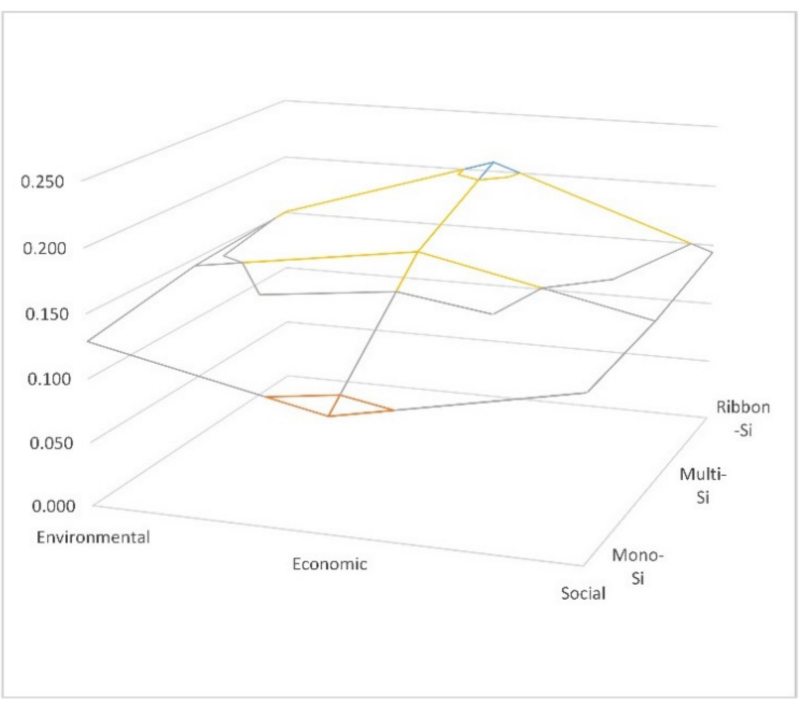

(b)

Figure 3. The scores for the selected PV technologies: (a) The scores concerning sustainability dimensions; (b) The relations between the selected modules in terms of environmental, economic, and social scores. Source: own elaboration.

Table 6. Sustainability score for each of the selected PV technologies in terms of environmental, economic, social.

\begin{tabular}{ccccccccc}
\hline & Mono-Si & Multi-Si & Ribbon-Si & Weights & Mono-Si & Multi-Si & Ribbon-Si \\
\hline Environmental & 0.386 & 0.433 & 0.453 & 0.333 & 0.129 & 0.144 & 0.151 \\
\hline Economic & 0.258 & 0.488 & 0.594 & 0.35 & 0.090 & 0.171 & 0.208 \\
\hline Social & 0.401 & 0.415 & 0.454 & 0.317 & 0.127 & 0.132 & 0.144 \\
\hline & & & Final score & 0.346 & 0.447 & 0.503 \\
\hline
\end{tabular}

Source: own elaboration.

For the environmental dimension, ribbon-Si scores 0.151 , multi-Si-0.144, while mono$\mathrm{Si}$ amounts to 0.129 . When it comes to the social concern, the results are similar to each other, ribbon-Si equals 0.144 , and $\mathrm{Si}-0.132$, while mono-Si is 0.127 . The biggest differences in scores can be seen within the economic dimension, where ribbon-Si is 0.208 , and multi-Si0.171 , while mono-Si scores 0.090 . The value of the string ribbon in this case is significantly higher than for the monocrystalline PV (almost twice higher). The relations between the selected modules and sustainability scores are depicted in Figure $3 b$.

From the selected technologies, the highest score is obtained by the string ribbon PV technology with a score equal to 0.503 . The second-best modules in line with the study assumptions are multicrystalline silicon photovoltaics (0.447). Monocrystalline silicon PV is proven to be the least sustainable with the score equal to 0.346 . This value is significantly lower than the results obtained by the alternative technologies. 


\section{Discussion}

The results showed that the best sustainability energy module was achieved by string ribbon technology. It amounted to the best outcomes gaining the highest sustainability result ( 0.503 vs. 0.447 vs. 0.346$)$. The least sustainable product occurred to be monocrystalline silicon photovoltaic modules, with a slightly worse outcome on the environmental and social dimensions, but with a significantly smaller score when it comes to the economic aspects. The biggest differences between the results for each of the selected photovoltaics are observed within the economic dimension. In this case, string ribbon PV has also been proved to provide the best performance. The main characteristic of these type of photovoltaic cells is found in their production process, generating the least material waste. It is $57 \%$ smaller than in the case of string ribbon PV. The outcomes of the assessment can be used for selecting the photovoltaic modules which resulted in the sustainability technology.

The findings of the study can provide useful information to energy policy decision makers at a national level to transform fossil fuels into cleaner energy, a more sustainable energy system (Wu et al., 2018), thus fostering the implementation of the energy union strategy [88].

One of the multifaceted challenges was to overcome a limitation in embodying the multicriteria decision for maximizing the energy policy, involving policy makers in the technology assessment. A supportive role of the integrated MCDM approach was aimed at providing a diagnosis of the macroeconomic situation. Thanks to that, practitioners can make a choice of a right sustainable technology.

The intention of the paper undoubtedly was the need for the unification of sustainability technology assessment in order to apply into mainstream energy policy, not only at the national level, but to activate support local industrial communities. This challenge fills in the existing gap, which lacks in the current energy policy in most host countries [89]. Table 7 presents future challenges and opportunities facing assessment in terms of its field of future impact on energy policies.

Table 7. Identification of energy related challenges and opportunities.

\begin{tabular}{cccc}
\hline Challenges & Opportunities & Challenges & Opportunities \\
\hline Regulation issues & $\begin{array}{c}\text { Provide consultants who } \\
\text { trained industrial } \\
\text { companies how to assess } \\
\text { energy technologies }\end{array}$ & $\begin{array}{c}\text { Lack of professional } \\
\text { experience }\end{array}$ & $\begin{array}{c}\text { Opportunities to learn } \\
\text { sustainability assessment based } \\
\text { on another companiesand } \\
\text { effective supervision }\end{array}$ \\
\hline Finance (Lack of funds) & $\begin{array}{c}\text { Presence of foreign funds } \\
\text { and supported } \\
\text { government of projects }\end{array}$ & $\begin{array}{c}\text { Inadequate preparation of } \\
\text { technology assessment }\end{array}$ & $\begin{array}{c}\text { Opportunity to learn from the } \\
\text { experienced company } \\
\text { in assessment }\end{array}$ \\
\hline Transformation into energy 4.0 & $\begin{array}{c}\text { Emergence of Internet of } \\
\text { Things (IoT technologies) } \\
\text { in smart energy metering }\end{array}$ & Energy systems network & $\begin{array}{c}\text { Energy system based on block } \\
\text { chain technology }\end{array}$ \\
\hline
\end{tabular}

Source: own elaboration.

While examining many sustainable assessment tools, it becomes obvious that multicriteria decision-making methods must be required to assess energy technologies, dedicated to implement them in the mainstream of energy policy in consequence. This method may allow for solving a particular "energy" problem based on the functions defined by the national authorities. For this reason, a design of the assessment method for the energyefficient policy which contributes to the EU's strategy is possible with multidisciplinary studies, starting from the emergence of the idea of new energy-anchored business models oriented on sustainability objectives.

This approach may be treated as a multidimensional technique to join many separate, independent methods to support involved stakeholders in a decision-making process.

The method can be perceived from two points of view: (1) requires a centralized overview by looking at the whole picture of technology and (2) "partial insight" by scanning 
the three domains of sustainability. These dimensions might be treated and visualized individually. A decision on which "version" of the method will be taken, should belong to the plant's decision-makers. Due to its holistic view, it might help decision-makers to better understand the idea of the application and to be better informed by providing local reporting, which can include data of how a given company meets the sustainability requirements or improves its sustainable performance.

Another possible use of the method is to determine which aspects of a given product need improvement. However, one must bear in mind, that not only the life cycle sustainability assessment which was used in this study, but in general, sustainability evaluations, are highly dependent on the criteria or indicators that in most cases are selected subjectively. Therefore, the assessment conducted in this study will only be useful if for the subject using the evaluation the same or similar criteria will be significant.

When trying to assess general market trends or product families, like in the aforementioned study, it is not enough to focus on the data coming from single producers but from the whole sector. In such situations, the collection of data might be rather time-consuming and generally more difficult. At the same time, comparison of specific products, for instance, specific models of PV modules, should not be as problematic as it does not require as much data and additional normalization that is implied by numerous sources specifying different characteristics in different units and measures.

In order to ensure the accuracy of the assessment numerous criteria should be used. The more criteria will be considered, the more authentic evaluation will be. It can lead to the necessity of searching through dozens of indicators, which can consume a lot of time. The most problematic dimension to be measured concerns social aspects. This problem was identified in many research papers, showing that social impact values are difficult to determine [90]. It may be mainly due to the lack of recommendations concerning criteria selection. Moreover, social aspects strongly depend on a region, local customs, and habits, which are unable to be compared between multiple cases.

The general problems and challenges that were recognized during this study correspond to the data availability. The biggest reason behind this is the fact that producers do not tend to publish data concerning their products as it might be used against them in the competitive market. Potential competitors might take advantage of public data. Hence, it is really hard to acquire verified information. That is the reason why aforementioned challenges regarding data limitations have occurred.

\subsection{The Effect of Sustainability Assessment on the Local Economy and Companies}

The study provides industrial plants with measures aimed at contributing their commitment to sustainability. It can also give useful data of companies' data to energy decisionmakers with which they can change their energy policy, and in consequence, shift national energy policy towards the transition respecting cleaner energy. Every industrial plant can contribute to energy sustainability by using tools, if implemented institutionally, to enhance its energy performance. The integrated MCDM-approach combining LCA-based methods and PESTEL may be used by researchers and practitioners of methods. The added-value of the method is to support local companies in their effective management of environmental, economic, and social issues, thus supporting the further development of energy initiatives at the local and national levels. On the contrary, the paper delivers a fresh look at PV market by analyzing it from different perspectives: PEST, MCDM-based assessment. Moreover, some suggestions could be proposed to build PV market sustainably. Thus, energy assessment could be a starting point for sustaining energy/making policy in a more effective manner.

\subsection{Designing Procedure for Sustainable Assessing Energy Technologies}

Due to the lack of analytical methods in the current energy policy, the challenge was to embody the developed sustainability assessment which helps in finding interaction between technology and the diverse energy policies. The applied methods in the integrated 
approach could be useful to select the best alternative technology or manufacturing processes by providing an optimum solution due to precise decisions. The assessment model presented in the paper plays a vital role as it can become a procedure for applying the method in regional or national energy strategy structures. Introduction of this approach could be a vital idea to supply the set of the evaluation approaches used for assessing energy effects or performance in an effective way. It creates a base for decision-makers to select appropriate tools.

If the difficulties in the multicriteria decision-making process appear, it might be addressed mainly by public administrations that are expected to implement a proposed evaluation mechanism in market regulations and criteria of subsidies and energy auctions.

\section{Managerial Implications}

With regard to managerial practice, the proposed integrated sustainability assessment method might provide industrial plants a tool/model for exploring sustainability features in energy technologies and making decisions related to its selection, evaluation, and management. When embodied within the energy policy, the model offers procedural assessment, which can be adopted and upgraded according to company-specific needs benefiting through the enhancement of company competitiveness. In addition, long-term growth and future investment for the industries might be prioritized.

Many of these companies will benefit most from the energy assessment model, especially by small and locally-owned companies, which will have to face LCA-oriented energy assessment increases in the future dictated by the EU.

On the other hand, the model gives information for companies to understand the possible negative effects of technology, therefore allowing them to reduce technology impact on the natural environment, increase social awareness, and maintain economic resources at the same time. Thanks to that, companies may contribute to improve their sustainability performances. Furthermore, by developing new assessment weights through the proposed model, practitioners can benchmark as reference points to those weights examined by researchers in the literature. In this case, companies could be assisted by creating a catalog that incorporates different target-oriented assessment criteria. This catalog can be regularly analyzed, updated, and interpreted related to the characteristics of energy technology.

The use of the proposed energy sustainability assessment method might be also beneficial for companies responsible for developing a sustainable energy policy, whose objective is to formulate a sustainable assessment method with its corresponding energy criteria. Even though the multicriteria sustainability assessment might be a beneficial challenge, it is an undertaking that clearly corresponds to the long-term development guidelines set by international organizations such as the United Nations or the European Union.

\section{Conclusions}

The research was intended to design an original, integrative multi-decision approach, supporting the assessment of the technologies performance for embodying the mainstream energy policy energy, simultaneously addressing the literature gap with regards to the lack of a sustainability assessment approach incorporating macroeconomic analysis in the multicriteria decision-making model. The assessment model was examined based on the real example of photovoltaic modules.

The results revealed the applicability of the sustainability technology assessment to support the making-decision process. The real example evidence gives the emphasis on the decision-making process to realize energy policy and in consequence, to improve enterprise sustainability performance. The assessment model solves multifaceted problems defined in Section 2.1 by delivering the aggregated and comprehensive sustainability assessment model to support the decision-making process for energy policy.

Additional research should be undertaken to consider the whole solar sector for renewable sources to confirm the applicability and usability of the proposed model in many 
industrial plants. In doing so, the model will be incorporated in mainstream energy for the automatization decision-making process. This model might be extended to provide the comparable analysis by using fuzzy impact criteria assessment $[18,91]$ and then strengthen by using sensitivity analysis [92] for the final decision or simulation, such as the Monte Carlo analysis. This simulation could solve the problem of uncertainty, vagueness in the decision-making process including environmental, economic, and social issues as well as technical information $[53,54]$. The study has outlined that the integrated approach might be embodied in MCDM as an inherent and suitable approach for sustainable energy multicriteria decision-making. This simple and efficient approach due to its comprehensibility of the computations may support decision-makers in their decision-making processes to select the right technology alternatives. On the other hand, it may be treated as a transitional tool to help in the assessment of energy technology towards energy sustainability [55].

A data-driven business model for collecting and managing real weights from the industries should be built in the future and updated periodically. This model further should be verified on the company's performance-based analysis.

Limitations of such an approach include high time and other resource costs for data collecting and conducting in-depth analysis like LCSA. The model provides a tool that might be incorporated within energy strategies, but it is not a panacea for sustainability challenges. Moreover, this model relies on data availability, hence data collection is a crucial yet difficult and time-consuming task.

Author Contributions: Conceptualization, M.K.; methodology, M.K., A.K.; software, A.K, M.K.; validation, M.K.; formal analysis, M.K.; investigation, M.K.; resources, A.K., M.K.; data curation, A.K., M.K.; writing-original draft preparation, M.K., A.K.; writing-review and editing, A.K., M.K.; visualization, A.K., M.K.; supervision, M.K, A.K.; project administration, M.K, A.K.; funding acquisition, M.K., A.K. All authors have read and agreed to the published version of the manuscript.

Funding: There was no external funding.

Institutional Review Board Statement: Not applicable.

Informed Consent Statement: Not applicable.

Data Availability Statement: The data that support the findings of this study are openly available at http:/ / viewer.webservice-energy.org/.

Conflicts of Interest: The authors declare no conflict of interest.

\section{References}

1. Weiss, E.B. United Nations Conference on Environment and Development. Int. Leg. Mater. 1992, 31, 814-817. [CrossRef]

2. UN. The United Nations Adoption of the Paris Agreement. Framework Convention on Climate Change. In Proceedings of the Conference of the Parties, Twenty-First Session, Paris, France, 12 December 2015.

3. EEA Overall Progress towards the European Union's “20-20-20” Climate and Energy Targets. 2019. Available online: https: / / www.eea.europa.eu/themes/climate/trends-and-projections-in-europe/trends-and-projections-in-europe-2017 / overall-progress-towards-the-european (accessed on 20 June 2021).

4. European Commission. Clean Energy for All Europeans. Communication from the Commission to the European Parliament, the Council, the European Economic and Social Committee, the Committee of the Regions and the European Investment Bank; European Commission: Brussels, Belgium, 2016.

5. Lotze-Campen, H. The Role of Modelling Tools in Integrated Sustainability Assessment (ISA). Int. J. Innov. Sustain. Dev. 2008, 3, 70-92. [CrossRef]

6. Lu, Y.; Khan, Z.A.; Alvarez-Alvarado, M.S.; Zhang, Y.; Huang, Z.; Imran, M. A Critical Review of Sustainable Energy Policies for the Promotion of Renewable Energy Sources. Sustainability 2020, 12, 5078. [CrossRef]

7. Sala, S.; Mathieux, F.; Pant, R. Life Cycle Assessment and Sustainability Supporting Decision Making by Business and Policy; John Wiley \& Sons, Ltd: Hoboken, NJ, USA, 2016; pp. 201-214.

8. Campos-Guzmán, V.; García-Cáscales, M.S.; Espinosa, N.; Urbina, A. Life Cycle Analysis with Multi-Criteria Decision Making: A Review of Approaches for the Sustainability Evaluation of Renewable Energy Technologies. Renew. Sustain. Energy Rev. 2019, 104, 343-366. [CrossRef]

9. Adenle, A.A. Assessment of Solar Energy Technologies in Africa-Opportunities and Challenges in Meeting the 2030 Agenda and Sustainable Development Goals. Energy Policy 2020, 137, 111180. [CrossRef] 
10. Taylan, O.; Alamoudi, R.; Kabli, M.; AlJifri, A.; Ramzi, F.; Herrera-Viedma, E. Assessment of Energy Systems Using Extended Fuzzy AHP, Fuzzy VIKOR, and TOPSIS Approaches to Manage Non-Cooperative Opinions. Sustainability 2020, $12,2745$. [CrossRef]

11. Dong, J.; Liu, D.; Wang, D.; Zhang, Q. Identification of Key Influencing Factors of Sustainable Development for Traditional Power Generation Groups in a Market by Applying an Extended MCDM Model. Sustainability 2019, 11, 1754. [CrossRef]

12. Baumann, M.; Weil, M.; Peters, J.F.; Chibeles-Martins, N.; Moniz, A.B. A Review of Multi-Criteria Decision Making Approaches for Evaluating Energy Storage Systems for Grid Applications. Renew. Sustain. Energy Rev. 2019, 107, 516-534. [CrossRef]

13. Javed, M.S.; Ma, T.; Jurasz, J.; Mikulik, J. A Hybrid Method for Scenario-Based Techno-Economic-Environmental Analysis of off-Grid Renewable Energy Systems. Renew. Sustain. Energy Rev. 2021, 139, 110725. [CrossRef]

14. Wang, J.; Jing, Y.-Y.; Zhang, C.-F.; Zhao, J.-H. Review on Multi-Criteria Decision Analysis Aid in Sustainable Energy DecisionMaking. Renew. Sustain. Energy Rev. 2009, 13, 2263-2278. [CrossRef]

15. Liu, Y.; Du, J. A Multi Criteria Decision Support Framework for Renewable Energy Storage Technology Selection. J. Clean. Prod. 2020, 277, 122183. [CrossRef]

16. Estévez, R.A.; Espinoza, V.; Ponce Oliva, R.D.; Vásquez-Lavín, F.; Gelcich, S. Multi-Criteria Decision Analysis for Renewable Energies: Research Trends, Gaps and the Challenge of Improving Participation. Sustainability 2021, 13, 3515. [CrossRef]

17. Vinodh, S.; Jayakrishna, K.; Kumar, V.; Dutta, R. Development of Decision Support System for Sustainability Evaluation: A Case Study. Clean Technol. Environ. Policy 2014, 16, 163-174. [CrossRef]

18. Bitter, J.; Printz, S.; Lahl, K.; Vossen, R.; Jeschke, S. Fuzzy Logic Approach for Sustainability Assessment Based on the Integrative Sustainability Triangle. In Proceedings of the 2016 World Congress on Sustainable Technologies (WCST), London, UK, 7-9 December 2016; pp. 64-69.

19. Wicher, P.; Zapletal, F.; Lenort, R. Sustainability Performance Assessment of Industrial Corporation Using Fuzzy Analytic Network Process. J. Clean. Prod. 2019, 241, 118132. [CrossRef]

20. Arvidsson, R.; Tillman, A.-M.; Sandén, B.A.; Janssen, M.; Nordelöf, A.; Kushnir, D.; Molander, S. Environmental Assessment of Emerging Technologies: Recommendations for Prospective LCA. J. Ind. Ecol. 2018, 22, 1286-1294. [CrossRef]

21. Saad Al-Sumaiti, A.; Kavousi-Fard, A.; Salama, M.; Pourbehzadi, M.; Reddy, S.; Rasheed, M.B. Economic Assessment of Distributed Generation Technologies: A Feasibility Study and Comparison with the Literature. Energies 2020, 13, 2764. [CrossRef]

22. Kühnen, M.; Hahn, R. Indicators in Social Life Cycle Assessment: A Review of Frameworks, Theories, and Empirical Experience. J. Ind. Ecol. 2017, 21, 1547-1565. [CrossRef]

23. Naegler, T.; Becker, L.; Buchgeister, J.; Hauser, W.; Hottenroth, H.; Junne, T.; Lehr, U.; Scheel, O.; Schmidt-Scheele, R.; Simon, S.; et al. Integrated Multidimensional Sustainability Assessment of Energy System Transformation Pathways. Sustainability 2021, 13, 5217. [CrossRef]

24. Beucker, S.; Bergesen, J.D.; Gibon, T. Building Energy Management Systems: Global Potentials and Environmental Implications of Deployment. J. Ind. Ecol. 2016, 20, 223-233. [CrossRef]

25. Hasan, A.S.M.M.; Trianni, A. A Review of Energy Management Assessment Models for Industrial Energy Efficiency. Energies 2020, 13, 5713. [CrossRef]

26. Hannouf, M.; Assefa, G. A Life Cycle Sustainability Assessment-Based Decision-Analysis Framework. Sustainability 2018, 10, 3863. [CrossRef]

27. Cinelli, M.; Coles, S.R.; Kirwan, K. Analysis of the Potentials of Multi Criteria Decision Analysis Methods to Conduct Sustainability Assessment. Ecol. Indic. 2014, 46, 138-148. [CrossRef]

28. Collotta, M.; Champagne, P.; Tomasoni, G.; Alberti, M.; Busi, L.; Mabee, W. Critical Indicators of Sustainability for Biofuels: An Analysis through a Life Cycle Sustainabilty Assessment Perspective. Renew. Sustain. Energy Rev. 2019, 115, 109358. [CrossRef]

29. Visentin, C.; Trentin, A.W.S.; Braun, A.B.; Thomé, A. Life Cycle Sustainability Assessment: A Systematic Literature Review through the Application Perspective, Indicators, and Methodologies. J. Clean. Prod. 2020, 270, 122509. [CrossRef]

30. Kriegler, E.; Petermann, N.; Krey, V.; Schwanitz, V.J.; Luderer, G.; Ashina, S.; Bosetti, V.; Eom, J.; Kitous, A.; Méjean, A.; et al. Diagnostic Indicators for Integrated Assessment Models of Climate Policy. Technol. Forecast. Soc. Chang. 2015, 90, 45-61. [CrossRef]

31. Zanghelini, G.; Cherubini, E.; Soares, S. How Multi-Criteria Decision Analysis (MCDA) Is Aiding Life Cycle Assessment (LCA) in Results Interpretation. J. Clean. Prod. 2017, 172. [CrossRef]

32. UN. WCED Our Common Future. World Comission on Environment and Development. In Proceedings of the WCED, Oslo, Norway, 20 March 1987.

33. Singh, R.K.; Murty, H.R.; Gupta, S.K.; Dikshit, A.K. An Overview of Sustainability Assessment Methodologies. Ecol. Indic. 2012, 15, 281-299. [CrossRef]

34. Sala, S.; Farioli, F.; Zamagni, A. Life Cycle Sustainability Assessment in the Context of Sustainability Science Progress (Part 2). Int. J. Life Cycle Assess. 2013, 18, 1686-1697. [CrossRef]

35. Achinas, S.; Horjus, J.; Achinas, V.; Euverink, G.J.W. A PESTLE Analysis of Biofuels Energy Industry in Europe. Sustainability 2019, 11, 5981. [CrossRef]

36. Kumar, A.; Sah, B.; Singh, A.R.; Deng, Y.; He, X.; Kumar, P.; Bansal, R.C. A Review of Multi Criteria Decision Making (MCDM) towards Sustainable Renewable Energy Development. Renew. Sustain. Energy Rev. 2017, 69, 596-609. [CrossRef] 
37. Dorini, G.; Kapelan, Z.; Azapagic, A. Managing Uncertainty in Multiple-Criteria Decision Making Related to Sustainability Assessment. Clean Technol. Environ. Policy 2011, 13, 133-139. [CrossRef]

38. Abotah, R.; Daim, T.U. Towards Building a Multi Perspective Policy Development Framework for Transition into Renewable Energy. Sustain. Energy Technol. Assess. 2017, 21, 67-88. [CrossRef]

39. Vučijak, B.; Kupusović, T.; Midžić-Kurtagić, S.; Ćerić, A. Applicability of Multicriteria Decision Aid to Sustainable Hydropower. Appl. Energy 2013, 101, 261-267. [CrossRef]

40. Özcan, E.C.; Ünlüsoy, S.; Eren, T. A Combined Goal Programming-AHP Approach Supported with TOPSIS for Maintenance Strategy Selection in Hydroelectric Power Plants. Renew. Sustain. Energy Rev. 2017, 78, 1410-1423. [CrossRef]

41. Çelikbilek, Y.; Tüysüz, F. An Integrated Grey Based Multi-Criteria Decision Making Approach for the Evaluation of Renewable Energy Sources. Energy 2016, 115, 1246-1258. [CrossRef]

42. Kaya, T.; Kahraman, C. Multicriteria Renewable Energy Planning Using an Integrated Fuzzy VIKOR \& AHP Methodology: The Case of Istanbul. Energy 2010, 35, 2517-2527. [CrossRef]

43. Ren, H.; Gao, W.; Zhou, W.; Nakagami, K. Multi-Criteria Evaluation for the Optimal Adoption of Distributed Residential Energy Systems in Japan. Energy Policy 2009, 37, 5484-5493. [CrossRef]

44. Kabak, M.; Dagdeviren, M. Prioritization of Renewable Energy Sources for Turkey by Using a Hybrid MCDM Methodology. Energy Convers. Manag. 2014, 79, 25-33. [CrossRef]

45. Perera, A.T.D.; Attalage, R.A.; Perera, K.K.C.K.; Dassanayake, V.P.C. A Hybrid Tool to Combine Multi-Objective Optimization and Multi-Criterion Decision Making in Designing Standalone Hybrid Energy Systems. Appl. Energy 2013, 107, 412-425. [CrossRef]

46. Claudia Roldán, M.; Martínez, M.; Peña, R. Scenarios for a Hierarchical Assessment of the Global Sustainability of Electric Power Plants in México. Renew. Sustain. Energy Rev. 2014, 33, 154-160. [CrossRef]

47. Troldborg, M.; Heslop, S.; Hough, R.L. Assessing the Sustainability of Renewable Energy Technologies Using Multi-Criteria Analysis: Suitability of Approach for National-Scale Assessments and Associated Uncertainties. Renew. Sustain. Energy Rev. 2014, 39, 1173-1184. [CrossRef]

48. Martin, M.; Røyne, F.; Ekvall, T.; Moberg, Å. Life Cycle Sustainability Evaluations of Bio-Based Value Chains: Reviewing the Indicators from a Swedish Perspective. Sustainability 2018, 10, 547. [CrossRef]

49. Martín-Gamboa, M.; Iribarren, D.; García-Gusano, D.; Dufour, J. A Review of Life-Cycle Approaches Coupled with Data Envelopment Analysis within Multi-Criteria Decision Analysis for Sustainability Assessment of Energy Systems. J. Clean. Prod. 2017, 150, 164-174. [CrossRef]

50. Kluczek, A. An Energy-Led Sustainability Assessment of Production Systems-An Approach for Improving Energy Efficiency Performance. Int. J. Prod. Econ. 2019, 216, 190-203. [CrossRef]

51. Stojčić, M.; Zavadskas, E.K.; Pamučar, D.; Stević, Ž.; Mardani, A. Application of MCDM Methods in Sustainability Engineering: A Literature Review 2008-2018. Symmetry 2019, 11, 350. [CrossRef]

52. Wu, Y.; Ke, Y.; Xu, C.; Li, L. An Integrated Decision-Making Model for Sustainable Photovoltaic Module Supplier Selection Based on Combined Weight and Cumulative Prospect Theory. Energy 2019, 181, 1235-1251. [CrossRef]

53. Mardani, A.; Jusoh, A.; Zavadskas, E.K.; Cavallaro, F.; Khalifah, Z. Sustainable and Renewable Energy: An Overview of the Application of Multiple Criteria Decision Making Techniques and Approaches. Sustainability 2015, 7, 13947-13984. [CrossRef]

54. Haddad, M.; Sanders, D. Selection of Discrete Multiple Criteria Decision Making Methods in the Presence of Risk and Uncertainty. Oper. Res. Perspect. 2018, 5, 357-370. [CrossRef]

55. Prasad, S.; Radhakrishnan, S.; Venkatramanan, V.; Kumar, S.; Kannojia, S. Sustainable Energy: Challenges and Perspectives. In Sustainable Green Technologies for Environmental Management; Springer: Berlin/Heidelberg, Germany, 2019 ; pp. 175-197. ISBN 9789811327711.

56. ISO 14040. Environmental Management_Life Cycle Assessment_Principles and Framework; ISO: Geneva, Switzerland, 2006.

57. ISO 14044. Environmental Management_Life Cycle Assessment_Requirements and Guidelines; ISO: Geneva, Switzerland, 2006.

58. Yao, Y.; Masanet, E. Life-Cycle Modeling Framework for Generating Energy and Greenhouse Gas Emissions Inventory of Emerging Technologies in the Chemical Industry. J. Clean. Prod. 2018, 172, 768-777. [CrossRef]

59. Vidal, R.; Sánchez-Pantoja, N. Method Based on Life Cycle Assessment and TOPSIS to Integrate Environmental Award Criteria into Green Public Procurement. Sustain. Cities Soc. 2019, 44, 465-474. [CrossRef]

60. Xu, D.; Lv, L.; Ren, J.; Shen, W.; Wei, S.; Dong, L. Life Cycle Sustainability Assessment of Chemical Processes: A Vector-Based Three-Dimensional Algorithm Coupled with AHP. Ind. Eng. Chem. Res. 2017, 56, 11216-11227. [CrossRef]

61. Saaty, T.L. Decision Making with the Analytic Hierarchy Process. Int. J. Serv. Sci. 2008, 1, 83-98. [CrossRef]

62. Ecoinvent. Available online: https:/ / www.ecoinvent.org/ (accessed on 29 June 2021).

63. Home / Webservice-Energy. Available online: http:/ / www.webservice-energy.org/ (accessed on 29 June 2021).

64. Jungbluth, N.; Dones, R.; Frischknecht, R. Life Cycle Assessment of Photovoltaics; Update of the Ecoinvent Database. MRS Proc. 2007, 1041. [CrossRef]

65. Wang, C.-N.; Van Thanh, N.; Nguyen, V.T.; Syed, T.H. A Multicriteria Decision-Making Model for the Selection of Suitable Renewable Energy Sources. Mathematics 2021, 9, 1318. [CrossRef]

66. Flanders Renewable Energy in Poland. Flanders Investment \& Trade: Poznan, Poland. 2019. Available online: https://www. flandersinvestmentandtrade.com/export/sites/trade/files/market_studies/2019-Poland-Renewable_Energy.pdf (accessed on 20 April 2021). 
67. Directive (EU) 2018/2001 Directive (EU) 2018/2001 of the European Parliament and of the Council of 11 December 2018 on the Promotion of the Use of Energy from Renewable Sources. PE/48/2018/REV/1 2018. Available online: https: / / eur-lex.europa. eu/legal-content/EN/TXT/?uri=CELEX\%3A32018L2001 (accessed on 20 June 2021).

68. IRENA. Renewable Power Generation Costs in 2019; International Renewable Energy Agency: Abu Dhabi, United Arab Emirates, 2020.

69. IRE. Photovoltaics in Poland 2020, Rynek Fotowoltaiki w Polsce 2020. 2020. Available online: https://ieo.pl/pl/aktualnosci/14 74-fotowoltaika-najlepiej-rozwijajaca-sie-technologia-oze-w-polsce (accessed on 21 June 2021). (In Polish).

70. EurObserv'ER. Webmaster Wind Energy Barometer 2017; EurObserv'ER: Paris, France, 2016.

71. Igliński, B.; Iglińska, A.; Cichosz, M.; Kujawski, W.; Buczkowski, R. Renewable Energy Production in the Łódzkie Voivodeship. The PEST Analysis of the RES in the Voivodeship and in Poland. Renew. Sustain. Energy Rev. 2016, 58, 737-750. [CrossRef]

72. PITA. Renewable Energy 2019. Available online: https:/ / www.iea.org/reports/renewables-2019 (accessed on 20 May 2021).

73. IRENA. Renewable Energy Employment by Country 2020; IRENA: Abu Dhabi, United Arab Emirates, 2020.

74. Pohjolainen, P.; Kukkonen, L.; Jokinen, P.; Poortinga, W.; Umit, R. Public Perceptions on Climate Change and Energy in Europe and Russia: Evidence from Round 8 of the European Social Survey. 2018. Available online: https://resulumit.com/papers/ pohjolainen2018.pdf (accessed on 23 April 2021).

75. IRENA. End-of-Life Management: Solar Photovoltaic Panels 2016; IRENA: Abu Dhabi, United Arab Emirates, 2016.

76. Ferrara, C.; Wilson, H.R.; Sprenger, W. 8-Building-integrated photovoltaics (BIPV). In The Performance of Photovoltaic (PV) Systems; Pearsall, N., Ed.; Woodhead Publishing: Sawston, UK, 2017; pp. 235-250. ISBN 978-1-78242-336-2.

77. IRENA. Renewable Energy Innovation: Accelerating Research for a Low-Carbon Future 2017; IRENA: Abu Dhabi, United Arab Emirates, 2017.

78. Mudgal, V.; Reddy, S.; Mallick, T. Techno-Economic Analysis of Standalone Solar Photovoltaic-Wind-Biogas Hybrid Renewable Energy System for Community Energy Requirement. Future Cities Environ. 2019, 5. [CrossRef]

79. Permien, F.-H.; Enevoldsen, P. Socio-Technical Constraints in German Wind Power Planning: An Example of the Failed Interdisciplinary Challenge for Academia. Energy Res. Soc. Sci. 2019, 55, 122-133. [CrossRef]

80. Tawalbeh, M.; Al-Othman, A.; Kafiah, F.; Abdelsalam, E.; Almomani, F.; Alkasrawi, M. Environmental Impacts of Solar Photovoltaic Systems: A Critical Review of Recent Progress and Future Outlook. Sci. Total Environ. 2021, 759, 143528. [CrossRef]

81. Bahtiarian, M. Noise Evaluations of Solar Energy Facilities. In Proceedings of the International Congress on Noise Control INTERNOISE and NOISE-CON Congress and Conference Proceedings, Seoul, Korea, 23-26 August 2020; Volume 262, pp. 663-672.

82. Abbasi, T.; Abbasi, S.A. Biomass Energy and the Environmental Impacts Associated with Its Production and Utilization. Renew. Sustain. Energy Rev. 2010, 14, 919-937. [CrossRef]

83. ISE. Photovoltaics Report 2020. Available online: https://www.ise.fraunhofer.de/content/dam/ise/de/documents/ publications/studies/Photovoltaics-Report.pdf (accessed on 20 June 2021).

84. Rosyid, O.A. Comparative Performance Testing of Photovoltaic Modules in Tropical Climates of Indonesia. AIP Conf. Proc. 2016, $1712,020004$.

85. Sheikh, N. Assessment of Solar Photovoltaic Technologies Using Multiple Perspectives and Hierarchical Decision Modeling. Ph.D. Thesis, Department of Engineering and Technology Management, Portland State University, Portland, OR, USA, 2013. [CrossRef]

86. Gjalt, H.; Lauran, V.O. Background Review of Existing Weighting Approaches in Life Cycle Impact Assessment (LCIA). 2011. Available online: https:/ / publications.jrc.ec.europa.eu/repository/handle/JRC67215 (accessed on 13 May 2021).

87. Dale, M. A Comparative Analysis of Energy Costs of Photovoltaic, Solar Thermal, and Wind Electricity Generation Technologies. Appl. Sci. 2013, 3, 325-337. [CrossRef]

88. EEA. A Framework Strategy for a Resilient Energy Union with a Forward-Looking Climate Change Policy. COM(2015) 80 Final. 2015. Available online: https:/ / eur-lex.europa.eu/resource.html?uri=cellar:1bd46c90-bdd4-11e4-bbe1-01aa75ed71a1.0001.03 /DOC_1\&format=PDF (accessed on 15 May 2021).

89. Olsen, K.; Fenhann, J. Sustainable Development Benefits of Clean Development Mechanism Projects. Energy Policy 2008, 36, 2819-2830. [CrossRef]

90. Sousa-Zomer, T.T.; Cauchick Miguel, P.A. The Main Challenges for Social Life Cycle Assessment (SLCA) to Support the Social Impacts Analysis of Product-Service Systems. Int. J. Life Cycle Assess. 2018, 23, 607-616. [CrossRef]

91. Mrówczyńska, M.; Skiba, M.; Sztubecka, M.; Bazan-Krzywoszańska, A.; Kazak, J.; Gajownik, P. Scenarios as a Tool Supporting Decisions in Urban Energy Policy: The Analysis Using Fuzzy Logic, Multi-Criteria Analysis and GIS Tools. Renew. Sustain. Energy Rev. 2021, 137, 110598. [CrossRef]

92. Ali, T.; Chiu, Y.-R.; Aghaloo, K.; Nahian, A.J.; Ma, H. Prioritizing the Existing Power Generation Technologies in Bangladesh's Clean Energy Scheme Using a Hybrid Multi-Criteria Decision Making Model. J. Clean. Prod. 2020, 267, 121901. [CrossRef] 